\section{In a sorry state}

Vera Rich reports on recent evidence of harassment of dissident Czechoslovak scientists

Czechoslovak scientists whose "moral and political requirements" fail to meet the official standard are not permitted to publish their scientific work. This was revealed by a 270-page White Paper on Czechoslovakia published last week the International Committee for the Support of Charter 77.

The Order was first made known in a letter from the Czechoslovak Ministry of Education to the Charles University, Prague, in May 1972, and in spite of protests has never been revoked. Since recent government moves against the Charter 77 movements include widespread dismissals of known signatories, the order on publication has taken on renewed importance.

One man who visited London to launch the White Paper, Dr Zdenek Mlynar, was dismissed from the Entomological Department of the National Museum for being a member by the International Committee for the campaign known as Charter 77'. Now in exile, he says that with the new waves of dismissals of the known Chartists from the Party and from professional employment, "Prague today is full of highly educated men sweeping the streets and stoking boilers".

These dismissals differ in one respect from those of the post-Dubcek repressions of 1970. Then it was primarily the social sciences which were hitoffending natural scientists were demoted but normally remained in their field of research. Today, however, the campaign against the Chartists makes no distinction between natural or social scientists; all are equally liable to dismissal, under the regulations on political attitudes.

These regulations, quoted in the white paper, actually antedate the Charter. The Directives of the Secretary General of the Academy of Sciences of July 1976 noted that "All creative and economic-technical employees shall have to be qualified in terms of politicals maturity ..."; and all leading "scientific workers" of the Academy were requested to complete a questionnaire concerning their political activities and Party status, and also that of their close relatives.

Following the appearance of the Charter, there was a wave of summary dismissals of known Chartists, including Dr Mlynar himself, from academic posts without the customary period of notice; it was "not possible" for the Chartists to remain during the normal termination period "without jeopardising the orderly fulfilment of the organisation's tasks." Under the 1972 regulations on publication, scientists thus dismissed not only lose their posts; they are unable to publish work in hand, or undertake such fringe activities as translation.
When the restrictions first became known, Dr Frantisek Janouch, in a letter of protest to the Minister of Education, Josef Havlin, pointed out that they would inhibit the dissemination of "valuable information on new findings" solely because their authors' "moral-political profile does not comply with a certain set of curious criteria which have never been publicly announced". In the case of the Chartists, the criteria are even more curious because the Charter and its subsequent documents make no demands which are not already stipulated either in the Czech constitution or in the international human rights agreements to which Czechoslovakia is a signatory.

Whatever the criteria, however, the dismissal of scientists and the ban on publication are a considerable threat to Czechoslovak science. It is already difficult, said Dr Mlynar, to function adequately as a scientist in Czechoslovakia: personal international contacts are now only $10 \%$ of what they were in 1968; foreign currency restrictions have brought about a general drop in the standard of equipment and in the accessibility of foreign journals.

Now there is also a threat to the next generation of scientists. A large collection of documents in the white paper presents unequivocal evidence that parents' political attitudes are a prime factor in deciding university admissions. Again, this trend antedates the Charter; Document 4 of the Chartist movement (23 January 1977) specifically calls for an independent inquiry into this practice. This demand has not been met.

\section{WEST GERMANY Saving it}

The West German government has plans to encourage energy saving. Werner Gries explains how

Conditioned by the oil crisis the Federal Republic of Germany has now moved energy-saving to the foreground of its energy policy. It has put special emphasis on reducing energy losses in electricity generation, saving energy in heating supply, and saving energy used by traffic.

On the domestic front low interest loans have been allocated to finance energy-saving measures. Definitive regulations about heat insulation for housing construction have been laid down in energy saving legislation and new buildings will have to be better insulated in future. Firing installations in residential buildings will also have to be made more efficient. This will increase the cost of building houses by approximately $3 \%$.

Industry is to be granted $7.5 \%$ of its expenditure on energy-saving investments and special investment credits are already available. In the public sector energy-saving measures are being considered in building plans and public education in energy saving is being intensified. In research, prototype projects for the efficient use of energy are being supported directly by the Research Ministry; over the past three years about DM500 million have been made available for this purpose.

The government is at present working out a detailed programme. At the heart of further domestic measures are investments to improve heat insulation and installations for heating supply. Heat pumps and solar collectors are also to be promoted through state allowances. The tenancy law is being altered to encourage energy saving. The government also wants to modify electricity tariffs and possibly make it a duty to mark the energy consumption on household appliances.

The focus in industry is on the coupling of electricity and heat production. An investment of DM2,400 million is to be spent on district heating up to 1980 . Thought is also being given to taxing cars with diesel engines less than those with petrol engines and new driving systems (methanol cars and electric cars for example) are being encouraged through tax incentives. Most of the government measures, however, will only complement private initiatives and interventions will be limited. 